\title{
BLAST-FURNACE PROCESS AS A SOURCE OF ANTHROPOGENIC MERCURY EMISSIONS
}

\author{
K. Kogut ${ }^{1}$, L. Tuz ${ }^{1}$, P. Burmistrz ${ }^{1}$ \\ ${ }^{1}$ AGH University of Science and Technology (Krakow, Poland)
}

E-mail: kogut@agh.edu.pl

\section{A UTHOR'S INFO \\ K. Kogut, Dr. Eng., Faculty of Energy and Fuels \\ L. Tuz, Dr. Eng., Faculty \\ of Metals Engineering and \\ Industrial Computer Science \\ P. Burmistrz, Dr. Eng., Prof., \\ Faculty of Energy and Fuels}

Key words:

mercury, blast furnace process, material balance, emission factor.

\author{
A B S T R ACT
}

The metallurgical industry is a major source of anthropogenic emissions of mercury, whose compounds have an adverse impact on the environment and human health. In the year 2017 in the European Union, the industry was responsible for nearly $13 \%$ of mercury emissions, being their third largest source. In Poland the industry is the fourth largest source of emissions, accounting for approximately $3.6 \%$ the total. There are several component processes in the steel production process. The first consists of the preparation of ferrous additive, mainly in the sintering process The second consists of smelting of pig iron in a blast furnace and the last entails processing in a converter or arc furnace. The main source of mercury in the blast furnace process is the fuel (coal and coke). The largest stream of mercury leaves the furnace with the blast furnace gas, which contains $2.4 \mu \mathrm{g} / \mathrm{m}^{3}$ after cleaning. Mercury content in pig iron has always been below detection levels with respect to analysis methods used. Using balance investigation results and data available in literature, an emission index has been determined for the whole production cycle: $10.181 \mathrm{mg} \mathrm{Hg} / \mathrm{Mg}$ of steel. This value consists of emissions generated in the following steps: preparation of sinter $-1.622 \mathrm{mg} \mathrm{Hg} / \mathrm{Mg}$ of steel, coke production $-4.953 \mathrm{mg} \mathrm{Hg} / \mathrm{Mg}$ of steel, combustion of blast furnace gas produced during the blast furnace process $-3.557 \mathrm{mg} \mathrm{Hg} / \mathrm{Mg}$ of steel and pig iron processing $-0.050 \mathrm{mg} \mathrm{Hg} / \mathrm{Mg}$ of steel.

\section{Introduction}

Given the toxicity of mercury and the global nature of its emissions, sources of emissions should be subject to monitoring and measures to minimize quantities of mercury compounds released into the environment [1-4]. Industrial processes are the main sources of anthropogenic mercury emissions, with the metallurgical industry playing a prominent role among these. Between 2007 and 2017, the metallurgical industry in the EU emitted nearly $100 \mathrm{t}$ of mercury [5-6].

At present, steel remains the primary material used in construction. Annual global steel production increased from 848.934 million $t$ in 2000 to 1816.611 million $t$ in 2018 [7]. Today, there are two main processes used to manufacture steel: (i) oxygen-blown converter (approximately $72 \%$ of steel production) and (ii) electric arc furnaces and induction furnaces (approximately $27 \%$ of steel production).

Pig iron for steel production is obtained by smelting in a blast furnace. Between 2007 and 2017, the volume of pig iron production in the EU varied between 116.3 million $t$ and 90.9 million $t$, with a minimum of 72.3 million $t$ due to the crisis in 2009. In Poland, production during the same period fluctuated from 5.8 million t to 4.8 million $\mathrm{t}$, with a minimum of 3.0 million $\mathrm{t}$ [8].

On a European scale, the pig iron and steel industry is identified as the third largest source of gaseous mercury emissions. The share of the pig iron and steel industry in global anthropogenic mercury emissions has decreased from about $1.86 \%$ in 2006 [2, 4] to about $1.34 \%$ in 2015 [9].

The main raw materials fed into the blast furnace are: (i) ferrous raw materials, (ii) fluxes and (iii) fuel. Blast fur- nace products include: (i) pig iron, (ii) blast furnace slag, (iii) blast furnace gas and (iv) blast furnace contaminants.

Ferrous raw materials supply iron into the blast furnace. They may be fed in to the furnace as sinter, pellets or lump ore. Authors of earlier papers report low mercury content in sinter (less than $5 \mu \mathrm{g} \mathrm{Hg} / \mathrm{kg}$ ) [10-12], although publications exist which report higher values, e.g. $19 \mu \mathrm{g} \mathrm{Hg} / \mathrm{kg}$ [13] or $45 \mu \mathrm{g} \mathrm{Hg} / \mathrm{kg}$ [14].

Fluxes are required to separate undesirable minerals released in the form of liquid slag. The mercury content varies widely depending on the flux used: $15-200 \mu \mathrm{g} \mathrm{Hg} / \mathrm{kg}$ $[11,12,15]$.

The main fuel used in the blast furnace process is coke. An additional fuel used to reduce coke consumption and improve the quality of pig iron is coal fed to the blast furnace using PCI (Pulverized Coal Injection) technology $[16,17]$. Mercury content in coke is not high, amounting to approximately $10 \mu \mathrm{g} \mathrm{Hg} / \mathrm{kg}[18,19]$. Mercury concentration in bituminous coal is usually much higher, amounting to as much as $200 \mu \mathrm{g} \mathrm{Hg} / \mathrm{kg}$ [20].

Mercury content in blast furnace slag released in liquid form from the surface of the pig iron is about $50.0 \mu \mathrm{g} \mathrm{Hg} / \mathrm{kg}[21,22]$.

Blast furnace gas is the largest product by mass of the blast furnace process, with a yield of approximately $2,800-3,500 \mathrm{~m}^{3} / \mathrm{t}$ of pig iron $(3,780-4,730 \mathrm{~kg} / \mathrm{t}$ of pig iron). Upon leaving the blast furnace, the gas is contaminated mainly by dust released in the inertial dust collector. Deep cleaning is performed in the scrubber, producing blast furnace sludge in the process. Available literature reports very high levels of mercury in blast furnace sludge approximately $1,630 \mu \mathrm{g} \mathrm{Hg} / \mathrm{kg}[23,24]$.

Mercury concentration in flue gases from a sintering furnace ranges from 20 to $70 \mu \mathrm{g} \mathrm{Hg} / \mathrm{m}^{3}[11,12]$ - a mercury 
emission index of $1.28-2.71 \mathrm{mg} \mathrm{Hg} / \mathrm{Mg}$ of sinter. On the other hand, mercury emissions to the atmosphere amount to $14.7 \mathrm{mg} \mathrm{Hg}$ per $1 \mathrm{t}$ of blast furnace coke produced in a coke plant [18]. In steel production processes on the other hand, the value of mercury emissions to the atmosphere is reported at approximately $0.05 \mathrm{mg} \mathrm{Hg} / \mathrm{Mg}$ of produced crude steel $[10,25]$.

The publication presents results of mercury balance investigations for an operating blast furnace. The results obtained, in combination with our previous research and literature reports enabled an analysis of mercury emissions for the complete production cycle, including: (i) sinter preparation process [11], (ii) coke production in a coke plant [18], (iii) blast furnace processes, and (iv) the steel production process [10].

\section{Experimental section}

The investigation included the following balances: mass and mercury in an operating blast furnace with a total volume of $2000 \mathrm{~m}^{3}$ and an efficiency of $175 \mathrm{t}$ of pig iron per hour.

Balance investigations were performed for an operating blast furnace; its operating diagram is well known from previous publications [26-28].

\subsection{Raw materials and products sampling}

Samples of raw materials fed to the blast furnace and of the pig iron produced were taken directly at the plant. 91 representative samples from all analyzed streams were collected over a 6 month period. Ferrous raw material samples were collected manually in accordance with the ISO 3082 standard [29], while samples of fuel (coke and coal) to the PCI were collected in accordance with the ISO 18283 standard [30]. Since there is no international standard that regulates flux (limestone, dolomite) collection methods, process additives and slag, adapted procedures described in the ISO 3082 and ISO 18283 standards were used in the investigation. Laboratory analysis results are presented in section 3.3.

\subsection{Analysis of fuels samples and raw materials in the blast furnace process}

Air-dried coal and coke samples were prepared in accordance with the ISO 13909 standard [31]. Analyses included proximate and ultimate analysis in accordance with ISO 17246 and ISO 17247 standards [32, 33] and mercury content with absorptive atomic spectrometry with cold vapour (CV-AAS) generation in an automated mercury analyzer DMA-80 (Milestone Connect). ISO 2596 and ISO 3087 standards were followed to determine moisture content in raw materials [34, 35]. Mercury content in solid samples of raw materials and blast furnace products was determined by adsorptive atomic spectrometry with cold vapour generation (CVAAS). Individual stream volumes were obtained based on control data generated by appropriate personnel of the Plant.

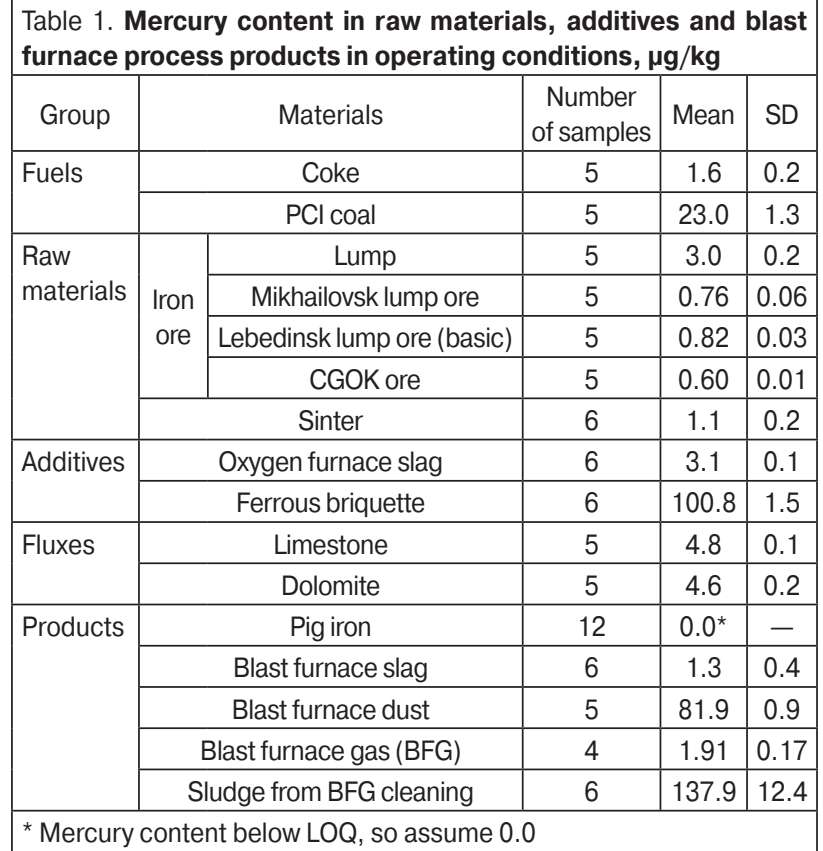

\subsection{Pig iron}

Mercury content in pig iron was investigated using a Phenom XL scanning electron microscope equipped with an integrated X-ray dispersion spectrometer (EDS) from ThermoFisher Scientific. Identification of elements was performed based on qualitative analysis using Elemental Mapping Software. Additionally, chemical composition tests were performed using a Foundry Master spark spectrometer.

Additionally, mercury content was determined by adsorptive atomic spectrometry with cold vapour generation using a DMA-80 (Milestone) analyzer. In the first step, pig iron filings were subjected to mineralization in a Berghof Speed Wave digester. Aqua regia was used as the digesting liquid. The solution obtained and a blank sample of aqua regia were analyzed with the DMA-80. No results were obtained indicating the presence of mercury in pig iron also in this case. Determination values in both samples (with analyte and blank) did not differ significantly. Therefore, mercury content in pig iron samples is below the limit of detection and the value in Table $\mathbf{1}$ was used for balance calculations.

\subsection{Blast furnace gas}

Gaseous phase mercury concentration in blast furnace gas was measured after the gas was cleaned in an inertial dust collector and scrubber.

Mercury content in blast furnace gas was determined using a system of traps filled with a proprietary sorbent mix consisting of coconut activated charcoal and Damasorb activated charcoal. The method was developed to measure mercury concentration in coke oven gas and adjusted during the investigation for measurements of mercury content in blast furnace gas. The method is described in detail in an earlier publication [36].

Mercury content was also analyzed in blast furnace gas contaminants. This was determined in dust from the inertial dust collector and in scrubber sludge. The analysis methodology was analogous to that described in section 2.2. 


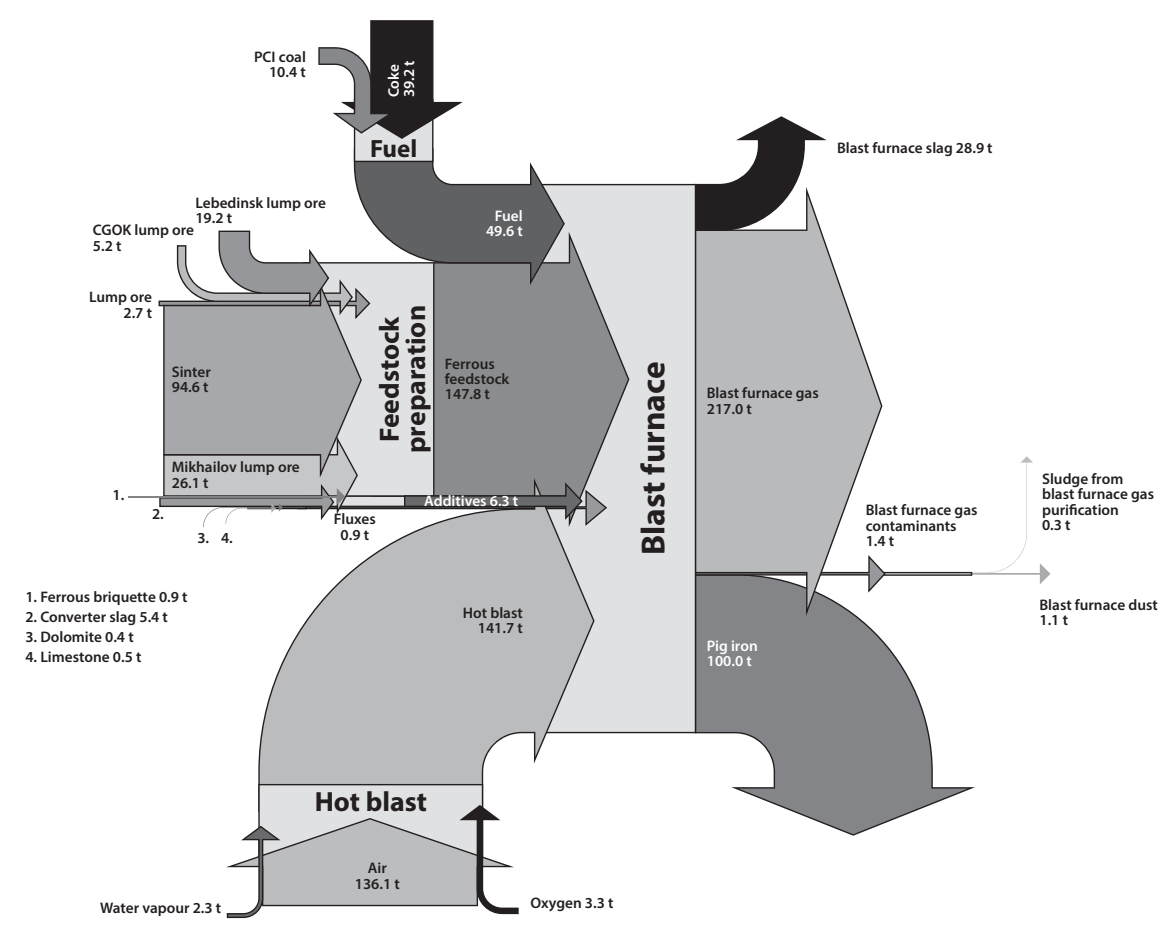

Fig. 1. Mass balance of blast furnace process. Stream values are referenced to $100 \mathrm{t}$ of produced pig iron

\subsection{Statistical analysis}

The following statistics were calculated for each parameter of the investigated raw minerals and products (clinker and cement): arithmetic mean, standard deviation (SD), variability coefficient $(\mathrm{CV})$, expected uncertainty at $95 \%$ confidence level.

The measure of reliability for a single examination of an analytical sample is the uncertainty of the result considered as the uncertainty that includes: sampling, preparation of the general sample, preparation of the laboratory and analytical samples, and the analysis itself. The detailed procedure was described in previous work [37].

\section{Results and discussion}

\subsection{Mass balance of blast furnace process}

Figure 1 shows the mass balance results of the investigated blast furnace. All values were referenced to $100 \mathrm{t}$ of produced pig iron.

Ferrous feedstock is the major raw material (45\%). The oxidant (hot blast with a temperature of approximately $1050{ }^{\circ} \mathrm{C}$ ) is present in similar quantity. In order to reduce the volume of the oxidant, it consists partly of pure oxygen (approximately $99.5 \%$ purity). In addition, a small amount of water vapour present in moist air is introduced into the stream. The fuel stream (coke and bituminous coal) amounts for a little in excess of $14 \%$ of all raw materials fed into the blast furnace.

The main product, that is pig iron, accounts for somewhat less than $30 \%$ of all output streams. The major product stream is blast furnace gas, amounting to approximately $62 \%$ of all products. Approximately $16,300 \mathrm{~m}^{3}$ of blast furnace gas is produced with each $1 \mathrm{t}$ of pig iron.

\subsection{Mercury analysis in the raw} materials and products of process

Validation studies have shown that the CV-AAS method (Direct Mercury Analyzer-80, Milstone) is accurate for fuel samples with mercury content ranging from 0.2 to $15 \mu \mathrm{g} / \mathrm{kg}$ in an air-dried basis. The limit of detection was $0.002 \mathrm{ng}$, while the limit of quantification was $0.006 \mathrm{ng}$. This method is highly linear $(r=0.9999)$, with $95 \%$ confidence level uncertainty ranging from 3 to $10 \%$, depending on range. Within the whole range of variability of measurement values, the CVAAS method demonstrates acceptable repeatability and reproducibility. Similar accuracy values were obtained for fuel samples (coal and coke). For other raw materials (limestone, dolomite, ferrous additive), the CV-AAS method was accurate for mercury concentrations from 1 to $150 \mu \mathrm{g} / \mathrm{kg}$ with relative uncertainty ranging from 2 to $12 \%$. The highest uncertainty values of $20 \%$ were observed for blast furnace slag samples with mercury content of approximately $1.3 \mu \mathrm{g} / \mathrm{kg}$.

\subsection{Mercury content in raw materials and products}

Table 1 shows analysis results of mercury content in collected samples of raw materials, fuels and blast furnace process products.

Mercury content in raw materials used in the pig iron smelting process was low, on the order of several $\mu \mathrm{g}$ of mercury per kilogram of raw material. The highest concentration of mercury was determined in lump ore - approximately $3.3 \mu \mathrm{g} / \mathrm{kg}$.

High mercury concentration was determined in ferrous briquette, an additive used in the blast furnace process, with values ranging from 99.3 to $102.7 \mu \mathrm{g} / \mathrm{kg}$.

The greatest mercury concentration was determined in sludge from the blast furnace gas cleaning process, varying from 79.7 to $327.8 \mu \mathrm{g} \mathrm{Hg} / \mathrm{kg}$. On the other hand, no mercury was determined in the produced pig iron. A discussion on the presence of mercury in pig iron is found in section 3.4. Mercury content in the other major product - blast furnace gas, is discussed in section 3.5.

\subsection{Mercury in pig iron}

Example photographs of analyzed sample areas with the elemental analysis are shown on the Fig. 2 and 3. During analysis, special focus was placed on areas of defects in the crystal lattice which could potentially contain contaminants, including mercury. As seen in Figure 3, such contamination (inclusions) appears, but mercury is not present.

Significant differences were found between the results of region and spot analyses. This is due to the selection of specific parts for spot analysis where mercury and other 

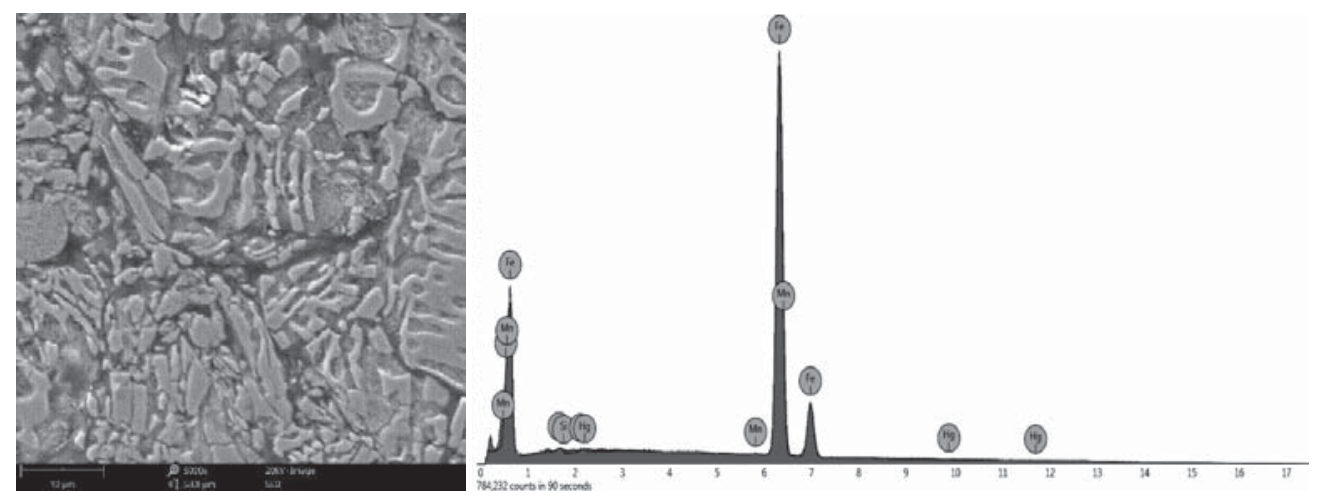

Fig. 2. Scanning microscope photograph and identification of elements present within the whole visible region covered by the photograph
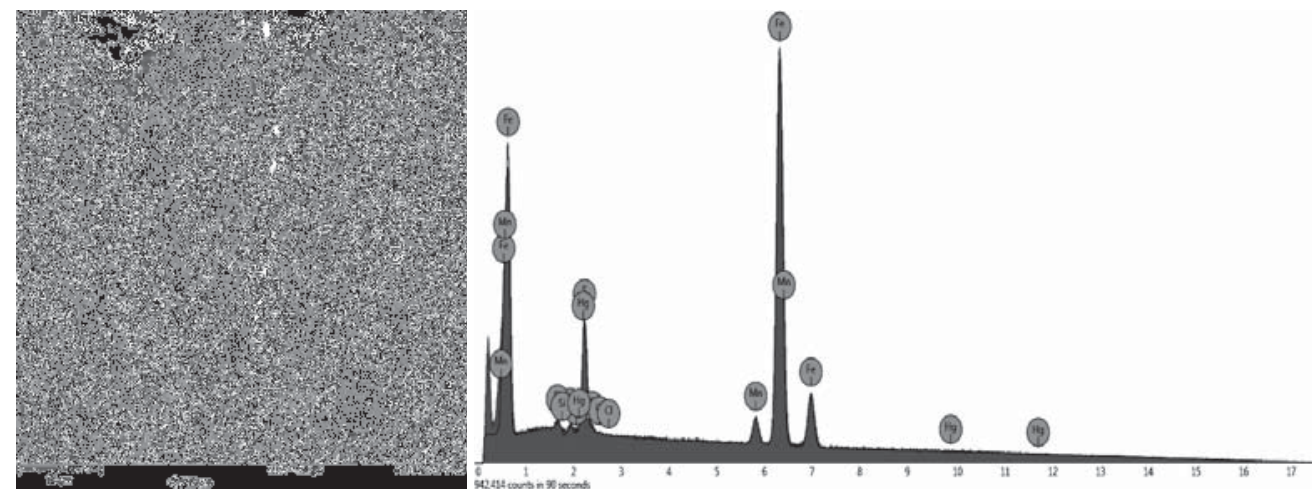

Fig. 3. Scanning microscope photograph and identification of elements present. The analysis was carried out in the spot marked with a "+"

both fly ash separated in electro-static filters and for coke dust separated in coke plant dust removal facilities [39-41].

\subsection{Mercury distribution}

Blast furnace mercury balance values shown in Fig. 4 are referenced to $100.0 \mathrm{t}$ of pig iron.

The highest mercury load $(302.0 \mathrm{mg} \mathrm{Hg})$ is introduced into the process with fuels: coal and coke, which introduce 238.7 and $63.3 \mathrm{mg} \mathrm{Hg}$ respectively. Thus, coal blown into the blast furnace (PCI) is the source of nearly $43 \%$ of the mercury in the process. The concentration of mercury in the PCI process was relatively low, amounting to $23.0 \mu \mathrm{g} \mathrm{Hg} / \mathrm{kg}$ on average, as compared to

inclusions could be present. Significant deviations from the expected values of the elements were observed, but no mercury was found. Similar results of elemental composition were obtained during analysis using the Foundry Master spark spectrometer.

\subsection{Mercury in blast furnace gas}

Average concentration of gaseous mercury $\left(\mathrm{Hg}^{0}\right.$ and $\mathrm{Hg}^{2+}$ ) in blast furnace gas was equal to $2.54 \mu \mathrm{g} \mathrm{Hg} / \mathrm{m}^{3}$, or $1.91 \mu \mathrm{g} \mathrm{Hg} / \mathrm{kg}$ of gas. Mercury concentration in blast furnace gas is clearly much lower than in another industrial gas used in steel plants, namely coke oven gas. Cleaned coke oven gas contains $3.2-7.5 \mu \mathrm{g} \mathrm{Hg} / \mathrm{m}^{3}[18,36]$. Considering that these gases are used as fuel, the emission potential of blast furnace gas is greater than that of coke oven gas. This is reflected in mercury content in blast furnace gas and coke oven gas with respect to their heating values: $0.7 \mu \mathrm{g} \mathrm{Hg} / \mathrm{MJ}$ and $0.2-0.4 \mu \mathrm{g} \mathrm{Hg} / \mathrm{MJ}$ respectively. Despite this, the factor is much lower than for solid fuels combusted in the Polish energy production sector. For brown and bituminous coals, these values are: $4.591 \mu \mathrm{g} \mathrm{Hg} / \mathrm{MJ}$ and $21.380 \mu \mathrm{g} \mathrm{Hg} / \mathrm{MJ}$ respectively [20].

Blast furnace dust (separated in the inertial dust collector) contained from 80.7 to $83.0 \mu \mathrm{g} \mathrm{Hg} / \mathrm{kg}$, while mercury content in blast furnace sludge (separated in the scrubber) varied widely, from 79.7 to $327.8 \mu \mathrm{g} / \mathrm{kg}$ in the analyzed samples. The correlation between dust particle size and mercury content, known from literature [38] was confirmed. The smaller the fraction, the higher the mercury content, adsorbed from the gaseous phase. An analogous relationship was observed for average mercury content in Polish sub-bituminous and bituminous coals, amounting to 104.0 and $75.9 \mu \mathrm{g} \mathrm{Hg} / \mathrm{kg}$ on average $[18,20]$. Mercury content in coal injected into blast furnaces is the major factor affecting the quantity of mercury introduced into the process. Coke introduced just under $11 \%$ of total mass of mercury introduced into the blast furnace and the stream volume in absolute terms is stable, amounting to $63.3 \mathrm{mg} \mathrm{Hg}$. This is due to a relatively stable value of unit consumption of coke (350-400 kg of coke/t of pig iron) and a low mercury content in coke resulting from the technology of coke production. At a temperature of $1300 \mathrm{~K}$ in the coking chamber, practically all of the mercury in the coking coal evaporates, leaving only a few $\mu \mathrm{g} \mathrm{Hg} / \mathrm{kg}$ in the produced coke.

A major stream of mercury (147 mg Hg - approximately $23.6 \%$ ) is introduced into the blast furnace with the ferrous feedstock. Sinter is the major component of this stream. With a mercury concentration of $1.1 \mu \mathrm{g} \mathrm{Hg} / \mathrm{kg}$ and a stream share by mass of $27.3 \%$, this accounts for $18 \%$ of mercury introduced into the blast furnace.

Additives are another major source of mercury, introducing $105.6 \mathrm{mg} \mathrm{Hg}$ (19\%). The major share here is contributed by ferrous briquette, with a concentration of $100.8 \mu \mathrm{g} \mathrm{Hg} / \mathrm{kg}$, introducing $17.8 \%$ of the mercury into the process.

Other streams of materials introduced into the process contribute marginally to the mercury balance of the analyzed system, with a total $558.8 \mathrm{mg} \mathrm{Hg} / 100 \mathrm{t}$ of pig iron.

Due to its high volatility and temperature conditions in the blast furnace, practically all of the mercury entering the 




Fig. 4. Mercury flow diagram for blast furnace process

blast furnace evaporates and leaves the furnace in the raw blast furnace gas stream. During cleaning of blast furnace gas, blast furnace dust is separated from the gas and sludge is produced in scrubbers. $90.5 \mathrm{mg} \mathrm{Hg}$ are contained in the dust stream and $24.3 \mathrm{mg} \mathrm{Hg}$ are in the sludge.

Cleaned blast furnace gas containing $2.54 \mu \mathrm{g} \mathrm{Hg} / \mathrm{m}^{3}$ $(1.91 \mu \mathrm{g} \mathrm{Hg} / \mathrm{kg}$ ) carries a load of $413.8 \mathrm{mg} \mathrm{Hg}$. This is due to the greatest share of this stream in the mass balance $(62.5 \%)$. Hence, the total mercury load leaving the blast furnace in raw blast furnace gas amounts to nearly $94 \%$. The remaining $6 \%$ of mercury leaves the blast furnace with slag ( $37.3 \mathrm{mg} \mathrm{Hg})$. As described in section 3.4 , the main blast furnace product - pig iron - does not contain mercury.

The concept of emission index of mercury to the atmosphere was not introduced because in the investigated system such emission did not occur. Emission will occur during combustion of blast furnace gas, but it will depend on how the process is carried out (quantity of supplied oxidant) and on flue gas cleaning facilities used. Emission of mercury to the atmosphere during the blast furnace process itself may occur during dust removal from the cast house. However, this source was outside of the balance boundary of the system used in the investigation.

Nevertheless, an attempt was made to present actual and potential emissions of mercury in a production cycle including: (i) sinter preparation (mercury emission index $2.0 \mathrm{mg} \mu \mathrm{g}$ $\mathrm{Hg} / \mathrm{t}$ of sinter [11]), (ii) coke production in coking plant (mercury emission index $14.7 \mathrm{mg} \mathrm{Hg} / \mathrm{t}$ of coke [18]), (iii) combustion of generated blast furnace gas for energy production (mercury emission index $1.91 \mathrm{mg} \mathrm{Hg} / 1000 \mathrm{~m}^{3}$ of gas), (iv) steel production process (mercury emission index $0.05 \mathrm{mg} \mathrm{Hg} / \mathrm{t}$ of steel [10].

Considering the mass balance of the blast furnace process (see section 3.1) and information available in literature on preparation of sinter, production of coke and the steel production process itself [42], the mercury emission index was calculated for the investigated production cycle. Its value is $10.181 \mathrm{mg} \mathrm{Hg} / \mathrm{t}$ of steel, including: (i) sinter preparation $1.622 \mathrm{mg}$ $\mathrm{Hg} / \mathrm{t}$ of steel (15.9\%), (ii) preparation of coke $4.953 \mathrm{mg} \mathrm{Hg} / \mathrm{t}$ of steel (48.6\%), (iii) combustion of blast furnace gas $3.557 \mathrm{mg} \mathrm{Hg} / \mathrm{t}$ of steel $(34.9 \%)$, (iv) steel production process $0.05 \mathrm{mg}$ $\mathrm{Hg} / \mathrm{t}$ of steel $(0.5 \%)$. The calculation of the mercury emission index from the combustion of blast furnace gas assumes the combustion of the entire volume of gas and absence of any device for removing mercury from the flue gas.

\section{Conclusions}

Raw materials fed into a blast furnace introduce $558.9 \mathrm{mg} \mathrm{Hg} / 100 \mathrm{t}$ or produced pig iron. This includes the following streams: (i) fuels (coal for PCI and coke) $302 \mathrm{mg} \mathrm{Hg} / 100$ t of pig iron (54\%), (ii) ferrous raw materials $-147 \mathrm{mg} \mathrm{Hg} / 100 \mathrm{t}$ of pig iron $(26.3 \%$ ), (iii) additives $109.9 \mathrm{mg} \mathrm{Hg} / 100 \mathrm{t}$ of pig iron $(19.7 \%)$.

Due to the temperature conditions in the blast furnace process, practically all mercury introduced with the raw materials moves to the raw blast furnace gas $(93.6 \%)$, while the remaining $6.4 \%$ remains in blast furnace slag.

After cleaning, blast furnace gas contains $2.54 \mu \mathrm{g} / \mathrm{m}^{3}$ $(1.91 \mu \mathrm{g} / \mathrm{kg})$ of mercury. Considering that blast furnace gas is a fuel used in steel plants, its mercury emission potential equals to $0.7 \mu \mathrm{g} \mathrm{Hg} / \mathrm{MJ}$ of heating value. The value of this index is comparable to coke gas and is more than ten times lower as compared to Polish hard and brown coals.

Mercury content in the main product of the process, i.e. pig iron, was below the limit of quantification of the analytical methods used, i.e. EDS and CV-AAS.

Results of investigations supplemented by available literature data made it possible to determine the mercury emission index for the steel production cycle entailing: (i) sinter preparation $-1.622 \mathrm{mg} \mathrm{Hg} / \mathrm{t}$ of steel, (ii) coke production $-4.953 \mathrm{mg} \mathrm{Hg} / \mathrm{t}$ of steel, (iii) combustion of gas generated in the blast furnace process $-3.557 \mathrm{mg} \mathrm{Hg} / \mathrm{t}$ of steel and (iv) the steel production process $-0.05 \mathrm{mg} \mathrm{Hg} / \mathrm{t}$ of steel. This results in an overall mercury emission index of $10.181 \mathrm{mg} \mathrm{Hg} / \mathrm{t}$ of steel. 
This research was financed from the AGH University of Science and Technology Research Subsidies no. 16.16.210.476 and 16.16.110.663.

\section{REFERENCES}

1. Global Mercury Assessment. United Nations Environment Programme (UNEP) Chemicals and Health Branch. Geneva. 2002.

2. Pacyna E. G., Pacyna J. M., Steenhuisen F., Wilson S. Global anthropogenic mercury emission inventory for 2000. Atmospheric Environment. 2006. Vol. 40 (22). pp. 4048-4063.

3. Pirrone N., Wichmann-Fiebig M., Ahrens R., Pacyna J. M. Borowiak A. Ambient Air Pollution by Mercury (Hg). Position Paper. European Communities. 2002.

4. Pirrone N., Cinnirella S., Feng X., Finkelman R. B., Friedli H. R., Leaner J., Mason R., Mukherjee A. B., Stracher G. B., Streets D. G., Telmer K. Global mercury emissions to the atmosphere from anthropogenic and natural sources. Atmospheric Chemistry and Physics. 2010. No. 10. pp. 5951-5964.

5. National emissions reported to the Convention on Long-range Transboundary Air Pollution (LRTAP Convention). European Economic Area (EEA). 2020. https://www.eea.europa.eu/dataand-maps/data/national-emissions-reported-to-the-convention-on-long-range-transboundary-air-pollution-lrtap-convention-13. Access: 2020-06-29.

6. European Pollutant Release and Transfer Register (E-PRTR). 2020. https://prtr.eea.europa.eu/. Access: 2020-06-19.

7. Poland's informative inventory report. Submission under the UN ECE Convention On Long-rate Transboundary Air Pollution and the Directive (EU) 2016/2284. 2015-2019. The National Centre for Emissions Management (NCEM). Warsaw. 2020

8. Steel Statistical Yearbook. 2009-2019. World Steel Association (WSA). Brussels. 2020.

9. Global Mercury Assessment 2018. United Nations Environment Programme (UNEP) Chemicals and Health Branch. Geneva. 2019.

10. Fukuda N., Takaoka M., Doumoto S., Oshita K., Morisawa S., Mizuno T. Mercury emission and behavior in primary ferrous metal production. Atmospheric Environment. 2011. Vol. 45. pp. 3685-3691.

11. Xu W., Shao M., Yang Y., Liu R., Wu Y., Zhu T. Mercury emission from sintering process in the iron and steel industry of China. Fuel Processing Technology. 2017. Vol. 159. pp. 340-344. DOI: 10.1016/j.fuproc.2017.01.033.

12. Yue T., Wang F., Han B. J., Zuo P. L., Zhang F. Analysis on Mercury Emission and Control Technology of Typical Industries in China. Applied Mechanics and Materials. 2013. Vol. 295-298. pp. 859-871.

13. Trinkel V., Mallow O., Thaler C., Schenk J., Rechberger H., Fellner J. Behavior of Chromium, Nickel, Lead, Zinc, Cadmium, and Mercury in the Blast Furnace - A Critical Review of Literature Data and Plant Investigations. Industrial \& Engineering Chemistry Research. 2015. Vol. 54 (47). pp. 11759-11771.

14. Wang F., Wang S., Zhang L., Yang H., Gao W., Wu Q., Hao J. Mercury mass flow in iron and steel production process and its implications for mercury emission control. Journal of Environmental Sciences. 2016. Vol. 43. pp. 293-301.

15. Wu Q., Gao W., Wang S., Hao J. Updated atmospheric speciated mercury emissions from iron and steel production in China during 2000-2015. Atmospheric Chemistry and Physics. 2017. Vol. 17. pp. 10423-10433.

16. Carpenter A. M. Use of PCI in blast furnace. IEA Clean Coal Centre. September 2006.

17. Matsui Y., Shibata K., Yoshida Y., Ono R. The Principle of Blast Furnace Operational Technology and Centralized Gas Flow by Center Coke Charging. Kobelco Technology Review. 2005. No. 25. pp. $12-20$.

18. Burmistrz P., Kogut K., Marczak M., Dziok T., Górecki J. Mercury in Polish Coking Bituminous Coals. Energy \& Fuels. 2018. Vol. 32. pp. 5677-5683

19. Konieczyński J., Zajusz-Zubek E., Jabłońska M. The Release of Trace Elements in the Process of Coal Coking. The Scientific World Journal. 2012. pp. 294927

20. Burmistrz P., Kogut K., Marczak M., Zwoździak J. Lignites and subbituminous coals combustion in Polish power plants as a source of anthropogenic mercury emission. Fuel Processing Technology. 2016. Vol. 152. pp. 250-258.

21. Das B., Prakash S., Reddy P. S. R., Misra V. N. An overview of utilization of slag and sludge from steel industries. Resources, Conservation and Recycling. 2007. Vol. 50 (1). pp. 40-57.

22. Wei Z., Wu G., Su R., Li C., Liang P. Mobility and contamination assessment of mercury in coal fly ash, atmospheric deposition, and soil collected from Tianjin, China. Environmental Toxicology and Chemistry. 2011. Vol. 30 (9). pp. 1997-2003.

23. Földi C., Dohrmann R., Mansfeld T. Mercury in dumped blast furnace sludge. Chemosphere. 2014. Vol. 99. pp. 248-253.

24. Földi C., Adrée C. A., Mansfeldt T. Sequential extraction of inorganic mercury in dumped blast furnace sludge. Environmental Science and Pollution Research. 2015. Vol. 22. pp. 15755-15762.

25. Technical Background Report for the Global Mercury Assessment 2013. United Nations Environmental Programme (UNEP) Division of Technology, Industry and Economics, Chemicals Branch. Geneva. 2013.

26. Sridhar S., McLean A., Guthrie R. Treatise on Process Metallurgy. Industrial Processes, Part A. Elsevier. 2014

27. Zhang W., Zhang J., Xue Z., Zou Z., Qi Y. Unsteady Analyses of Top Gas Recycling Oxygen Blast Furnaces. ISIJ International, Advance Publications by J-STAGE. 2016. Vol. 90. pp. 1-10.

28. Sun W., Wang Q., Zhou Y., Wu J. Material and energy flows of the iron and steel industry: Status quo, challenges and perspectives. Applied Energy. 2020. Vol. 268. pp. 114946. DOI: 10.1016/j. apenergy.2020.114946.

29. ISO 3082. Iron ores. Sampling and sample preparation procedure. International Organization for Standardization. Geneva. Switzerland. 2017

30. ISO 18283. Hard coal and coke. Manual Sampling. International Organization for Standardization. Geneva. Switzerland. 2006.

31. ISO 13909-4. Hard coal and coke. Mechanical sampling. Part 4. Coal-Preparation of test samples. International Organization for Standardization. Geneva. Switzerland. 2001

32. ISO 17246. Coal - Proximate analysis. International Organization for Standardization. Geneva. Switzerland. 2010.

33. ISO 17247. Coal - Ultimate analysis. International Organization for Standardization. Geneva. Switzerland. 2013.

34. ISO 2596-4. Iron ores. Determination of hydrogenic moisture in analytical samples. Gravimetric, Karl Fischer and mass-loss methods. International Organization for Standardization. Geneva. Switzerland. 2006.

35. ISO 3087. Iron ores. Determination of the moisture content of a lot. International Organization for Standardization. Geneva. Switzerland. 2011

36. Górecki J., Burmistrz P., Trzaskowska M., Sołtys B., Gołaś J. Method development for total mercury determination in coke oven gas combining a trap sampling method with CVAAS detection. Talanta. 2018. 188. 293-298.

37. Burmistrz P., Kogut K. Mercury in Bituminous Coal used in Polish Power Plants. Archives of Mining Sciences. 2016. Vol. 61 (3). pp. 473-488.

38. Kadirvelu K., Kavipriya M., Karthika C., Vennilamani N., Pattabhi S. Mercury (II) adsorption by activated carbon made from sago waste. Carbon. 2004. Vol. 42. pp. 745-752.

39. Bhardwaj R., Chen X., Vidic R. D. Impact of Fly Ash Composition on Mercury Speciation in Simulated Flue Gas. Journal of the Air \& Waste Management Association. 2009. Vol. 59 (11). pp. $1331-1338$

40. Clack H. L. Modeling Mercury Capture within ESPs: Continuing Development and Validation. Electrostatic Precipitators. Springer. Berlin. 2009. pp. 37-44.

41. Veselý V., Szeliga Z., Vávrová Z., Čech B., Regucki P., Krzyżyńska R. Characteristic of Mercury on the Surface of Ash Originating from Electrostatic Precipitators of Lignite and Bituminous Coalfired Power Plants. Environment Protection Engineering. 2019. Vol. 45 (4). pp. 45-59.

42. Remus R., Aguado Monsonet M. A., Roudier S., Sancho L. D. Best Available Techniques (BAT) Reference Document for Iron and Steel Production. Industrial Emissions Directive 2010/75/ EU. Integrated Pollution Prevention and Control. European Commission JRC Reference Report. BREF. 2013. 